\title{
1. Reducing Poverty: The Overall Framework
}

\author{
GUY PFEFFERMANN AND GARY S. FIELDS
}

How private firms contribute to economic mobility and poverty reduction and what governments can do to enhance their contribution is the theme of this book. We look first at the positive role the private sector plays in economic development, a role that has received less emphasis that that of other players. We then focus on the labor market and how various mechanisms in the economy interact to affect conditions for people as workers and as consumers. The volume examines the links among the business environment, private sector development, economic growth, poverty reduction, and economic mobility.

Until recently, development economists tended to assume a role for private enterprises in reducing poverty, without articulating it explicitly. Then the new institutional economics literature, with its emphasis on transaction costs, began to focus on the environment in which private businesses operate in various countries-the "investment climate." Given subsequent surveys and research reports, including some published in this volume, we are now in a much better position than even five years ago to identify areas of the investment climate in which improvements should yield substantial growth benefits.

\section{PEOPLE MOVING OUT OF POVERTY}

Our starting point is the worldwide drop in the number of very poor people, the first such drop in almost two centuries (see Figure 1-1).

Because world population has kept on increasing, the drop in the share of poor people is even sharper: thirty years ago, about 17 percent of the world's population 


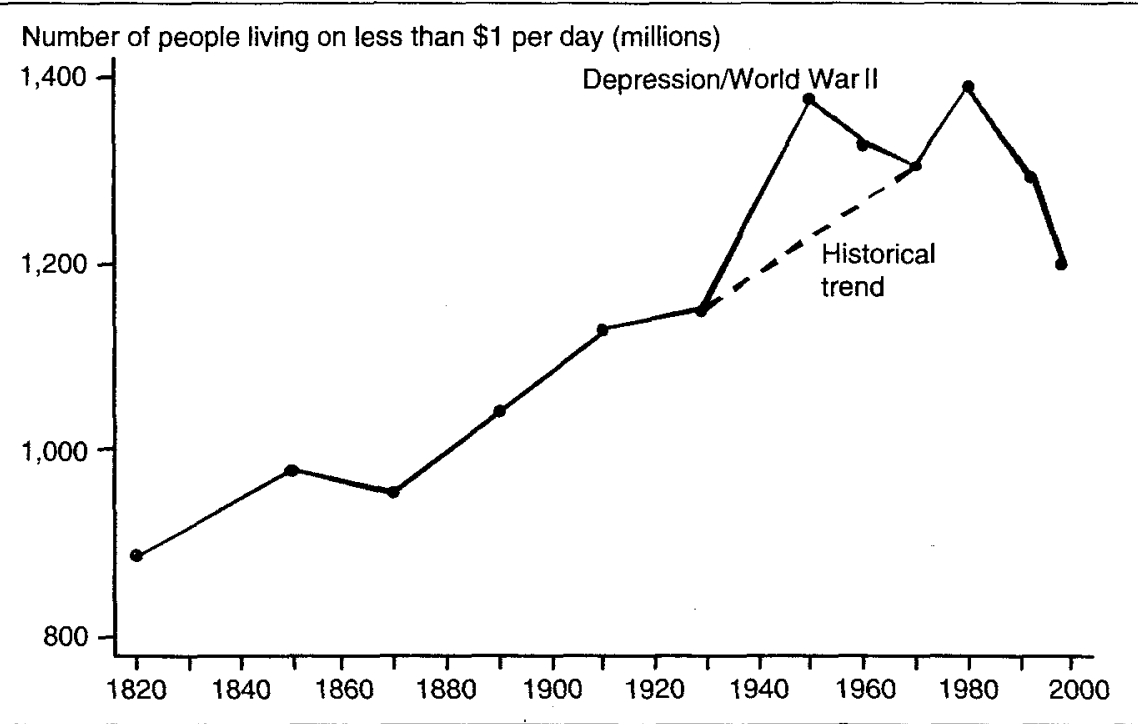

Figure 1-1. World Poverty, 1820-1998.

Source: David Dollar, World Bank.

were living in extreme poverty; today fewer than 7 percent are (see Sala-I-Martin 2002). Of course, some countries and some regions did better than others. Perhaps most encouraging, in the world's most populous countries, China and India, the number of extremely poor persons declined substantially. Only in the former Soviet Union did the number of people living in extreme poverty increase. The question arises, How do people move out of poverty?

\section{WHAT PRIVATE FIRMS CONTRIBUTE TO DEVELOPMENT}

In developing countries, private enterprise is far and away the largest source of employment and investment and a significant source of government revenue. In addition to these tangible contributions, private enterprise is an important source of less tangible, but critically important, factors such as openness to ideas, innovation, and opportunity. ${ }^{1}$ While state-owned firms can in theory deliver the same benefits to society, in practice they seldom do so, owing to multiple and often conflicting objectives set by government and delayed or inflexible responses to economic change and market conditions. In contrast, private firms operating in competitive conditions obtain "real-time" feedback from the markets, which is a condition of long-term dynamism.

\section{Employment}

More and better jobs offer the best (often the only) opportunity for upward mobility in the lifetimes of poor people and their children. Upward mobility is key to securing the ultimate objects of development: freedom from hunger, long life, health, greater choice, and generally more human fulfillment. 
Poor people themselves certainly seem to think so. In interviews with Rio de Janeiro favela and low-income housing complexes, 69 percent said that finding a job was the most important thing in life (see Figure 1-2).

Data on job creation by private firms are few and far between. Table 1-1 shows that the vast majority of jobs are created by private firms and not by government, including state-owned enterprises.

In addition to job creation, upgrading both jobs and skills is an important pathway out of poverty. Successful long-run development brings with it massive occupational shifts, in the course of which poverty, however defined, is reduced. Upgrading within sectors of activity (from subsistence agriculture to market agriculture, for example) or

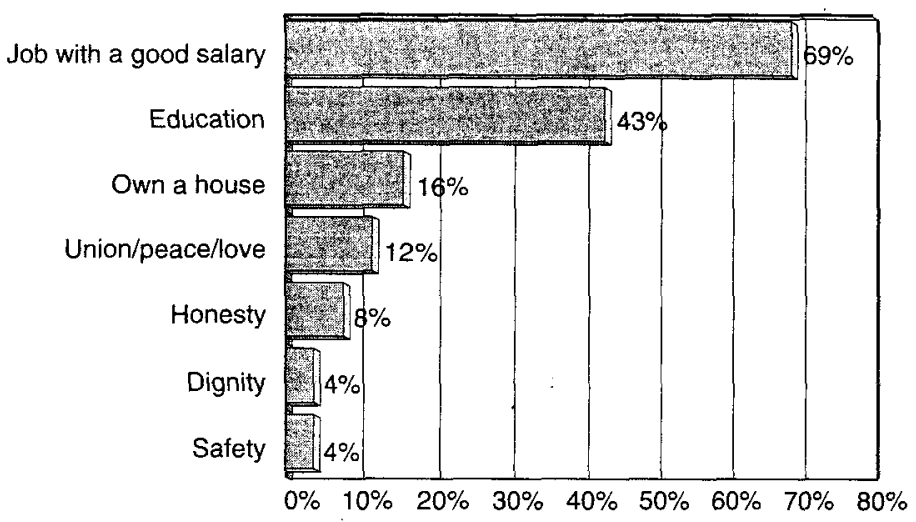

Figure 1-2. Factors Most Important for a Successful Life.

Source: Chapter 9, "Marginality: From Myth to Reality in the Favelas of Rio de Janeiro, 1969-2002," in Ananya Roy and Nezar Al Sayyad, eds., Urban Informality, Lexington, Mass.: Lexington Books, forthcoming.

Table 1-1 Private Firms as a Source of Job Creation, Selected Developing Countries, 1987-98

\begin{tabular}{lrrrr}
\hline & & \multicolumn{2}{c}{\begin{tabular}{l} 
Job creation (thousands) \\
\cline { 2 - 3 }
\end{tabular}} & \multicolumn{2}{l}{ Private } & Public & $\begin{array}{l}\text { Ratio of private job } \\
\text { creation to public job } \\
\text { creation }\end{array}$ \\
\hline Mexico & $1989-98$ & $12,431.0$ & 143.0 & $87: 1$ \\
Costa Rica & $1994-98$ & 238.0 & 12.0 & $20: 1$ \\
Turkey & $1987-92$ & $1,490.0$ & 91.0 & $16: 1$ \\
Kenya & $1993-98$ & 173.0 & 13.0 & $13: 1$ \\
Guatemala & $1994-98$ & 47.0 & 4.0 & $12: 1$ \\
Bolivia & $1994-97$ & 181.0 & 18.0 & $10: 1$ \\
Uruguay & $1987-92$ & 127.0 & 27.0 & $4.7: 1$ \\
Gabon & $1992-96$ & 4.7 & 1.3 & $3.6: 1$ \\
\hline
\end{tabular}

Source: IMF, Recent Economic Developments (various years, for each country). 
shifts between sectors (for instance, from agriculture to manufacturing) are key to achieving development. Upgrading jobs and skills is central to these processes, and private firms are the major source of demand for higher levels of skills and jobs.

\section{Tax Revenues}

There would be no sustainable and reliable base for funding programs that benefit poor people, such as health, education, social safety nets, and agricultural research, without a foundation of private economic activities. Formal sector enterprises - small, medium, and large-generate the taxes that finance the bulk of government expenditure critical to any poverty reduction effort.

In developing countries, private firms are a major source of tax revenue that supports social services and other publicly backed assistance to poor people. While in some of the poorest countries, foreign aid plays an important role, it cannot be regarded as a substitute for a country's own efforts. It is too small in most countries and is not reliable.

\section{Investment}

Private investment has a major role to play in economic growth. Recent studies have shown that it is more closely associated with growth than is public investment. It also tends to embody newer technologies and more capital than public investment. That is the conclusion of a study of 50 developing countries from 1970 to 1998 that examines the relationship between private and public investment, growth rates, and income levels (see Bouton and Sumlinski 2000).

The study found that the association between private investment and growth was even more pronounced during the $1990 \mathrm{~s}$, a period when private investment was accelerating in many countries, while public investment was declining as a result of privatization and tighter budget constraints.

\section{Openness to Ideas}

The sources of long-term economic growth are often intangible. No single factor such as investment or education can "ignite" development. Much depends, rather, on the pace at which poor societies can adapt knowledge that already exists in the more economically advanced parts of the world and put it to use. The challenge is how to bring about conditions in which knowledge accumulated over decades, and indeed centuries, can be usefully absorbed and effectively utilized in poorer countries.

Successful developing countries are open to foreign ideas; they nurture "receptors" capable of filtering out those strands of knowledge that can take root in their local environment. Throughout the world, private enterprises act as knowledge receptors. Where competitive conditions prevail, leading enterprises will constantly seek out information that has practical uses locally. To remain competitive, other firms, in turn, will emulate their behavior. In this process, executives and employees upgrade their human capital, their productivity, and their incomes.

The role of private firms in absorbing knowledge and putting it to use is especially important in the process of technology generation and diffusion. Private companies 
play a major part in research and development. In the course of development, the share of gross domestic product spent on research and development increases, and private companies undertake most of it. Private businesses also bring innovations to the marketplace in the form of products, services, and processes, thus broadening choices for poor people as well as more affluent consumers.

Whether, and to what extent, private firms have the incentives to make these contributions to development depends in large part on the business environment, including, significantly, the degree of competition that firms are facing. Monopolies, oligopolies, high protection against competing imports, and government subsidies tend to reduce the contribution that private firms are making to development. Competition is the most effective way to avoid concentration of power, oligarchy, corruption, and collusion between firms and government.

Until the mid-1990s, when Political Credibility and Economic Development was published, little was known across developing countries about their investment climates. ${ }^{2}$ Until then, researchers and policymakers had to rely on "expert surveys," which tended to focus mainly on political risk or on the environment for foreign firms. The authors of Political Credibility and Economic Development applied a questionnaire to local as well as foreign firms in 28 developing countries, with a primary focus on the predictability of the legal and regulatory framework and its enforcement.

A more ambitious Worldwide Business Environment Survey was conducted as part of the World Bank's 1997 World Development Report, The State in a Changing World. That survey encompassed 69 countries and 3,600 firms and focused on the predictability of rule making, crimes against persons and property, reliability of judicial enforcement, and the degree of corruption. Lack of institutional credibility was found to translate into less investment as well as lower returns on development projects.

A second Worldwide Business Environment Survey was carried out during 1999 and 2000, covering about 10,000 firms in 80 countries and West Bank and Gaza (see http://www.worldbank.org/privatesector/ic/ic_ica_resources.htm). Chapters 9 and 10 of this book are based on that survey, the most comprehensive of its kind.

\section{THE BOOK'S STRUCTURE AND MAIN MESSAGES}

The book consists of four parts. The first focuses on economic mobility and some of the main factors that encourage the upward movement of people. Chapter 2 presents sets of surveys about households in Indonesia, South Africa, Spain, and Venezuela. These sets are unique because they make it possible to trace individual households over time. The surveys were conducted during the 1990s, a decade of intensifying globalization, and are therefore of particular interest. The data indicate that poor households participated at least proportionately in the economic growth that has taken place. In all four countries, initially poor households experienced more favorable income changes, in relation to their initial incomes, than their richer counterparts. In none of the countries does the evidence support statistically significant conditional divergence, whereby the rich get relatively richer and the poor get relatively poorer. Changes in labor earnings are more important than changes in all other sources of household income combined. Transitions out of or into poverty are most strongly 
influenced by changes in the head of household's employment. A switch to public sector employment by the household head substantially increases the likelihood of escaping from poverty but accounts for relatively few such escapes. Most households that escaped poverty were headed by private sector workers.

Chapter 3 also focuses on four economies-Taiwan (China), Indonesia, Costa Rica, and Brazil--and considers the longer-term relationship between economic growth (or the absence thereof) and the evolution of labor markets. The authors challenge the view that in today's globalized world, economic growth no longer leads to poverty reduction. The results cast doubt on two claims: that a large proportion of workers are being left out of economic growth today and that workers participated in economic growth before but are no longer able to do so now. In the four economies, workers benefited during growth periods. The economic growth that occurred was transmitted through the labor market with a movement to higher-paying jobs, substantial increases in real income, a more educated labor force, decreases in unemployment, and lower poverty. The chapter builds a new database and provides fresh, detailed evidence on long-term economic mobility.

Chapter 4 focuses mainly on Latin America, where the informal sector is very prevalent and is generally believed to'offer much worse employment conditions than do formal, officially registered firms. A variety of evidence is pulled together in support of the view that "informal" entrepreneurship can be a viable, and often desirable, alternative to formal sector salaried work. The evidence includes surveys with entrepreneurs, field studies, and cross-country data. Contrary to widely accepted perceptions, given a worker's education and skills, the difference between what he or she might earn in a formal enterprise and what he or she may earn in the informal sector is far from clear-cut. What emerges, rather, is that formal and informal activities tend to command different packages consisting of wages, benefits, independence, and entrepreneurial potential. Formal sector labor protections are not free; workers often pay for them in salary deductions and also in lower equilibrium wages. Should the value of benefits to the worker fall below this "implicit tax," he or she may wish to shift to the informal sector, where earnings are entirely monetary. The chapter concludes that the informal sector can be viewed as an entrepreneurial breeding ground, which many people join by choice, not by necessity.

Part II of the book deals with case studies from different parts of the world. The longrun development of Korea is analyzed in chapter 5. The author stresses the importance of high-productivity, high-paying jobs as a means to achieve both growth and equity ("shared growth") and of the right mix of private enterprise and government intervention in encouraging development and lifting people out of poverty into the middle class. The chapter documents how Korea achieved an enviable measure of success in generating shared growth. One of the key factors is the mutually supportive long-term interplay between productivity improvements and the educational upgrading of the labor force. The chapter also stresses the importance of industrial relations in the development process; as well as the role of small and medium enterprises (SMEs).

Chapter 6 is concerned with formerly Communist countries and with China and documents the crucial role that private entrepreneurs are playing in determining how 
successful the reform process is. New firms have been formed at a striking rate in some of the transition countries and, as in other economies, improving welfare by creating jobs and supplying consumer goods. In economies moving away from central control, new private enterprises are also playing a crucial role in constraining the market power of the state-owned firms and building political momentum for reform. We summarize evidence on the relative role of entrepreneurs and the state in economic reform. Different reforming countries have experienced very different degrees of economic and social success. The rate of new enterprise creation is a particularly powerful predictor of success or failure. The chapter considers entry, entrepreneurial strategies, the welfare effects of private enterprises, and the need for state support, especially in enforcing contracts and creating conditions under which private firms can obtain financing.

In chapter 7 , the focus shifts to Palanpur, a tiny Indian village in the densely populated gangetic plain of western Uttar Pradesh-perhaps the only one in the world for which detailed economic data have been collected for nearly half a century. Through this lens, the authors try to gather insights about the mechanisms by which India's long-term economic progress may translate into changing living conditions in rural communities. Progress has been slow, always at the mercy of weather conditions; yet over the long haul, living standards have improved markedly. As noted in the preface, the real purchasing power of even the poorest agricultural laborers doubled between the late 1950 s and the mid-1980s. Improvements in agricultural productivity are key to such progress. Yet improved productivity might have been offset by rapid population increase had it not been for increasing demand for labor outside farming. Responding to this demand by private firms in nearby towns, an increasing number of people took to commuting. While this did not always translate into higher incomes for the poorest segments of the village population, it did relieve population pressure on the land. Indeed, a growing relative agricultural labor scarcity pushed up rural wages, and this played a fundamental role in raising living standards of Palanpur's poor in the long run.

Some of the problems of Sub-Saharan African entrepreneurship are considered in chapter 8 . The analysis draws on heretofore unpublished survey data of African enterprises. The focus is on the personal characteristics of entrepreneurs and their educational and family backgrounds. Such endowments influence powerfully the types of opportunities that they can exploit. The survey shows very clearly that ethnic African entrepreneurs are much less likely to have had prior experience in their industry or higher education or to have strong business networks, foreign connections, or significant financial assets, compared to minority entrepreneurs of European, Asian, and Middle Eastern descent. As a consequence, in many cases, African entrepreneurs are constrained to enter manufacturing by way of informal apprenticeships and start-ups of micro and small firms. These firms also tend to remain smaller and less productive. Attention by policymakers needs to be paid particularly to improving the availability of technical, vocational, and enterprise-based training, as well as increased access to working capital.

Part III considers the importance of good business environments (or "investment climates") to successful economic and social development. The rich materials of the 
Worldwide Business Environment Survey mentioned earlier in this chapter serve to make the case. In chapter 9 the "voices of the firms" are heard. Executives of 10,000 companies, most of them small local firms, evaluated the obstacles they face. The survey also gathered "objective" data such as sales and investment volumes and so made it possible to assess the impact of changes in the investment climate on firm performance. Survey results are also presented and analyzed by regions.

While the findings of this overview chapter are complex, in simple terms the analysis confirms the clear importance of a few key constraints for firm growth and investment: financing problems, high taxes, corruption, policy uncertainty, and insufficient business consultation. The chapter also explores the factors associated with firms operating informally, finding informality positively associated with macroeconomic constraints (such as inflation and exchange rate uncertainty), regulatory and tax constraints, corruption, and weak protection of intellectual property rights. The chapter also finds that while most firms suffer from poor business environments, in some countries powerful firms "capture the state" and shape the investment climate to their benefit, thereby harming most other enterprises.

Chapter 10 also draws on the business environment survey and asks whether small, medium, and large firms have different sensitivities to various state imperfections. A number of obstacles to doing business are being examined such as corruption, policy uncertainty, access to financing, taxes, and regulations. For most obstacles, firm size and how strongly firms are being affected by obstacles are negatively associated. There are, however, some exceptions, and each country's circumstances need to be examined individually. The finding of a bias against small firms supports continued targeted policy efforts, but the author cautions against neglecting reforms that benefit the investment climate for all firms.

This leads naturally to the book's last part, which is concerned with public policy and public attitudes. Chapter 11 presents a promising approach to helping small and medium enterprises compete. Smaller enterprises tend to be less export oriented than larger firms. This raises concerns about their future in an increasingly globalized world economy. Governments have been trying to help smaller firms for decades but have had little impact on enterprise competitiveness. Governments and donors are therefore searching for new approaches. The authors suggest such a new approach, using links between companies to build the capabilities of small and medium enterprises and increase their participation in local and global markets. This strategy has the potential to overcome some of the main impediments facing these small firms and positioning them for greater growth and job creation. Unlike traditional support programs, this approach is market based.The chapter includes the description of concrete cases where this approach is being tested.

Chapter 12 turns to broad strategies that governments can pursue to enhance the capacity of poor people to move up the economic ladder. Three sets of policies are capable of reducing insecurity and enhancing the opportunities of the poor as well as the middle class. The first of these is more broadly available social services, including education. The second is removing market and policy distortions that block the productive potential of poor people. The third is better safety nets and other forms of 
social insurance. How much governments are able to level the playing field or tilt it in favor of poor people will depend to a large extent on public attitudes toward who should benefit from government efforts, on the balance between formal and informal sectors, on fiscal and administrative capacity, and on the political lie of the land. The chapter shows how attitudes about individual prospects for upward mobility-as well as individual experiences with upward or downward mobility-both influence and are influenced by the policy context and in turn help determine the actual behavior and effort level of individuals in particular societies.

\section{REFERENCES}

Borner, Silvio, Aymo Brunetti, and Beatrice Weder. 1995. Political Credibility and Economic Development. New York: St. Martin's Press.

Bouton, Lawrence, and Mariusz Sumlinski. 2000. "Trends in Private Investment in Developing Countries: Statistics for 1970-1998." IFC Discussion Paper No. 41. Washington, D.C.: International Finance Corporation.

International Finance Corporation. 2000. Paths Out of Poverty: The Role of Private Enterprise in Developing Countries. Washington, D.C.

Sala-I-Martin, Sala, 2002. "The World Distribution of Incorne." NBER Working Paper No. w8933.

World Bank. 1997. World Development Report: The State in a Changing World. Washington, D.C.: World Bank.

\section{NOTES}

${ }^{1}$ This section draws on Paths Out of Poverty:The Role of Private Enterprise in Developing Countries, IFC 2000.

${ }^{2}$ The European Roundtable of Industrialists (http://unwuert.be) did publish periodic surveys in cooperation with the United Nations and the International Chamber of Commerce, but these surveys focused only on perceptions by multinational corporation executives. 